\title{
THE IMPACT OF EDUCATIONAL COUNSELING ON THE ALTERATION OF ATHLETIC IDENTITY AMONG ADOLESCENTS
}

\author{
Vinga Rakauskienė, Audronė Dumčienė \\ Lithuanian Academy of Physical Education, Kaunas, Lithuania
}

\begin{abstract}
Research background and hypothesis. The article deals with the manifestation of athletic identity of senior students of secondary schools as a major precondition for the development of physical education among adolescents and health-favouring lifelong physical activity (Anderson, 2004; Bélanger, et al., 2011). The hypothesis of the paper is that under educational counseling, the evaluations of athletic identity among adolescents increase.

Research aim was find out the impact of educational counseling (EC) on the alteration of athletic identity (AI) of adolescents.

Research methods. In order to evaluate AI among adolescents, a methodology of EC was employed. To reveal issues faced by adolescents, questions of four types were employed: Exception, Miracle, Coping and Scale questions together with PA definition questions (International Physical Activity Questionnaire short form). The evaluation of AI was performed with the Athletic Identity Questionnaire for Adolescents as developed by C. B. Anderson, L. C. Mâsse and A. C. Hergenroeder (2007) consisting of forty statements which were evaluated in the Likert scale from 1 to 5 by the research participants.

The research involved 553 students ( 294 females and 259 males) whose age average was $16.75 \pm 1.11$ years. The students were randomly assigned to EC impact (253 students) and comparison (300 individuals) groups. The members of the impact group were counseled from one to six times regarding PA and other problems while the adolescents constituting the comparison group merely indicated their PA and other issues; they were not counseled.

Research results. The evaluation of AI and its constituent parts in the impact and comparison groups were not statistically significant before $\mathrm{EC}(\mathrm{p}>0.05)$.

During the period of EC, the values of AI and its constituents regarding the importance of PA and incentives to be involved in PA statistically significantly improved in the adolescents facing problems connected with PA of the impact group.

EC was more efficient for those adolescents who were not sufficiently involved in classes of physical education. They showed significant $(\mathrm{p}<0.05)$ improvement not only in terms of AI but also concerning the values of the importance of PA and the evaluations of social incentives (general incentives).

Discussion and conclusions. EC positively impacted the alteration of AI among adolescents. During the period of EC, statistically significant $(\mathrm{p}<0.05)$ improvement was observed in the evaluations of AI regarding its constituent parts, the importance of PA and incentives for PA among the adolescents who had been facing problems linked to PA. The AI values statistically significantly $(p<0.05)$ increased in both males and females during the period of EC. The impact of EC on the athletic identity was insignificant $(p>0.05)$ in adolescents exhibiting problems in communication with teachers of physical education.
\end{abstract}

Keywords: educational counseling, athletic identity, physical activity.

\section{INTRODUCTION}

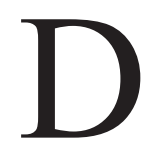

uring the period of adolescence, selfidentification and the evolution of the identity of the personality represent a process of crucial importance (Shek, Wong, 2011). During this period, further development of adults, their value attitudes and consequently 
their behavior are also shaped (Shek, Wong, 2011). During adolescence, both females and males are concerned about their looks, weight and body shapes, they feel less satisfied with their personal "self" (Lawler, Nixon, 2011).

The self-reflection directs the attention of an individual in a certain direction and relates with the self-esteem of the individual. The clearly conceived physical self directs the adolescent to clearly motivated behavior regarding being physically active or inactive (Weiss, Williams, 2004).

The self-reflection of the physical "self" becomes more and more important in everyday life, especially among the youth and adolescents (Laus et al., 2011).

When regarding the realization of one's "self" as a multidimensional component, athletic identity represents its inseparable part; according to C. B. Andersen (2004), it consists of four segments: looks, importance, competence and incentives (for physical activity). These segments may be laid out in several levels exhibiting a principle of hierarchy. The present research highlights incentives by parents and friends. When promoting physical activity among adolescents, the importance of social incentives is singled out (Bélanger et al., 2011). It is believed (Anderson et al., 2007) that constituents of athletic identity are related to the physical activity of adolescents.

It has been observed that those adolescents whose athletic identity is more prominent do better in their studies, miss fewer classes and have less behavioral problems at school (Videon, 2002). On the other hand, individuals denoted by more prominent athletic identity get involved in athletic activity more frequently (Tasiemski et al., 2004).

The aim of the research was to discover the impact of educational counseling on the alteration of athletic identity in adolescents.

The object of the research was the alteration of athletic identity among adolescents.

The hypothesis was that under the impact of educational counseling, values of athletic identity among adolescents would improve.

\section{RESEARCH METHODS}

A methodology of educational counseling on the grounds of the method of solution focused brief counseling (Simon, Berg, 1999) was applied in order to evaluate its impact on the athletic identity of adolescents. The philosophy of educational counseling is based on the idea that an adolescent possesses many strengths and is able to change himself/herself and his/her life.

The methodology of educational counseling is oriented towards solutions in a developing troublesome situation from the point of view of the adolescent; the empathic attitude of the counselor to the global outlook of the adolescent, the employment of the strengths and internal powers and the establishment of positive relationship between the adolescent and the counselor are applied; specific and clear objectives are outlined during the course of counseling.

In order to reveal problems faced by adolescents, questions of four types were employed:

Exception questions enable the adolescent to spot the moments when the problem which is the cause of counseling is not present and to reflect the moments when the outlined difficulty is not manifested or is rarer/ less prominent or not so significant.

Miracle questions (miracles are often expected in counseling sessions) evoke situations when the problem to be solved is nonexistent anymore. The behavior of the client is sought to be discovered in a situation when the problem no longer exists and it becomes the objective when seeking the fulfillment of adolescent's objectives and expectations. Questions also prompt the adolescent to undertake responsibility of making objectives and expectations come true.

Coping questions seek to reveal the strengths of the adolescent by discovering how s/he manages to achieve the state so that the situation does not get worse. Coping questions are most useful when the adolescent is unmotivated to deal with his/her problem or believes that there is no solution in his/ her situation.

Scale questions are employed to get the adolescent evaluate the complexity of his/her problem and his/her determination to change or do something to decrease the problem.

Activity definition questions strive to find out the behavior of the adolescent when the problem is no longer present. The definition of activities helps to evaluate changes as the expectations and objectives of the adolescent are more clearly defined and transparent.

At the end of an educational counseling session, the adolescent is presented with assignments in the 
form of suggestions contributing to "reorientation" of the adolescent towards individual search for the solution of the problem.

In order to evaluate physical activity, the adapted (Lekečinskaite, 2009) seven-question short form of the International Physical Activity Questionnaire was employed. This is the most efficient and widely used method for the establishment of subjectively measured physical activity of an individual (Lee et al., 2011).

The evaluation of athletic identity was performed with the adapted Athletic Identity Questionnaire for Adolescents (Anderson et al., 2007) constituting 40 statements (e. g. After illness or injury, I begin exercising/doing physical activity again as soon as possible or I really like to be physically active) assessed in Likert scale from 1 to 5 by the research subjects; $1=$ I completely disagree with the statement; 2 = I partially disagree with the statement; $3=$ I neither agree nor disagree with the statement; $4=$ I partially agree with the statement; 5 = I fully agree with the statement. The Lithuanian scale adaptation was made by the authors of the article preparing double translation and cooperating with Prof. C. B. Anderson.

The total internal consistency of the 40 statements of the Athletic identity questionnaire for adolescents was verified by Cronbach's alpha of 0.934 while its separate subscales exhibited the following numerical values: looks (Cronbach's alpha 0.820), competence (Cronbach's alpha 0.808), importance (Cronbach's alpha 0.887), general incentive (Cronbach's alpha 0.912), incentive by parents (Cronbach's alpha 0.844) and incentive by friends (Cronbach's alpha 0.857); hence the questionnaire was suitable for use in the research.

Before performing calculations, the correspondence of data distribution to the regular distribution was checked by employing Kolmogorov-Smirnov and Shapiro-Wilk criteria.

The verification of statistical significance of value average differences was calculated with Student's $t$ criterion at the level of significance $\mathrm{p}<$ 0.05 by employing SPSS version 17.0.

\section{PARTICIPANTS OF THE RESEARCH}

The research involved 553 students (294 females and 259 males) whose age average was $16.75 \pm 1.11$ years. The students were randomly assigned to education counseling impact (253 students) and comparison (300 students) groups. The age and group distribution of male and female participants was not statistically significant $(\mathrm{p}>0.05)$. The members of the impact group were counseled from one to six times regarding physical activity and other problems (the average number of counseling sessions was $3.93 \pm 0.98$ regarding physical activity and other problems) while the adolescents constituting the comparison group merely indicated their physical activity and other problems; they were not counseled. Permission from principles of the participating schools were obtained; all the students participated in the research voluntarily and were aware of the confidentiality of the research data.

\section{RESEARCH RESULTS}

The data of the impact group and comparison group in terms of athletic identity of the adolescents facing problems connected with physical activity and the constituent elements of athletic identity are presented in Table 1.

The values of athletic identity and its constituents before educational counseling were not statistically significantly different among the impact and comparison group adolescents $(\mathrm{p}>0.05)$.

The data on the level of athletic identity and its constituents in males and females are presented in Table 2.

The results of the research revealed that athletic identity of males was statistically significantly more prominent in comparison with females. Differences were established when comparing specific constituents in the male and female groups as well. It was found that males valued their athletic competence and the importance of physical activity. The general incentive and the incentive produced by parents to be physically active manifested at a statistically significantly higher level in males than in females. Significant differences were not observed between males and females only in the evaluation of their sporty looks and regarding the friends' incentive to be physically active.

Data on the alteration of athletic identity and its constituent elements in adolescents of the impact group facing problems connected with physical activity during the period of educational counseling EC (M, SD) are presented in Table 3.

During the period of educational counseling, the values of athletic identity and its constituents, 
Table 1. Values of athletic identity and its constituents before educational counseling (M, SD)

Table 2. Manifestation of athletic identity and its constituent elements in males and females (M, SD)

\begin{tabular}{|l|c|c|c|c|}
\hline \multicolumn{1}{|c|}{ Variables } & Impact group & Comparison group & t & p \\
\hline Athletic identity & $3.45 \pm 0.62$ & $3.48 \pm 0.73)$ & 0.31 & 0.752 \\
\hline Constituents of athletic identity & $3.88 \pm 0.76$ & $3.86 \pm 0.86$ & -0.15 & 0.875 \\
\hline Competence & $3.65 \pm 0.84$ & $3.79 \pm 0.96$ & 1.29 & 0.196 \\
\hline Looks & $3.50 \pm 0.88$ & $3.53 \pm 0.93$ & 0.28 & 0.778 \\
\hline Importance & $3.14 \pm 0.93$ & $3.00 \pm 0.96$ & -1.19 & 0.232 \\
\hline Incentive by parents & $2.72 \pm 0.92$ & $2.83 \pm 0.97$ & 1.00 & 0.314 \\
\hline Incentive by friends & $2.79 \pm 0.80$ & $2.74 \pm 0.81$ & -0.50 & 0.616 \\
\hline Incentive, general & & & & \\
\hline
\end{tabular}

\begin{tabular}{|l|c|c|c|c|}
\hline \multicolumn{1}{|c|}{ Variables } & Males & Females & $t$ & $\boldsymbol{p}$ \\
\hline Athletic identity & $3.62 \pm 0.71$ & $3.37 \pm 0.68$ & 4.21 & $\mathbf{0 . 0 0 0 1}$ \\
\hline Constituents of athletic identity & $4.06 \pm 0.76$ & $3.73 \pm 0.86$ & 4.78 & $\mathbf{0 . 0 0 0 1}$ \\
\hline Competence & $3.80 \pm 1.05$ & $3.76 \pm 0.81$ & 0.47 & 0.633 \\
\hline Looks & $3.82 \pm 0.87$ & $3.31 \pm 0.90$ & 6.71 & $\mathbf{0 . 0 0 0 1}$ \\
\hline Importance & $3.18 \pm 0.93$ & $2.89 \pm 0.94$ & 3.57 & $\mathbf{0 . 0 0 0 1}$ \\
\hline Incentive by parents & $2.85 \pm 0.95$ & $2.81 \pm 0.96$ & 0.55 & 0.579 \\
\hline Incentive by friends & $2.83 \pm 0.76$ & $2.70 \pm 0.82$ & 1.99 & $\mathbf{0 . 0 4 6}$ \\
\hline Incentive, general & & &
\end{tabular}

Table 3. The alteration of athletic identity and its constituent elements in adolescents of the impact group facing problems with physical activity during the period of educational counseling (M, SD)

\begin{tabular}{|l|c|c|c|c|}
\hline \multicolumn{1}{|c|}{ Variables } & Before EC & After EC & $t$ & $p$ \\
\hline Athletic identity & $3.45 \pm 0.62$ & $3.53 \pm 0.59$ & -4.22 & 0.0001 \\
\hline Constituents of athletic identity & $3.88 \pm 0.76$ & $3.91 \pm 0.77$ & -0.71 & 0.479 \\
\hline Competence & $3.65 \pm 0.84$ & $3.67 \pm 0.85$ & -1.42 & 0.158 \\
\hline Looks & $3.50 \pm 0.88$ & $3.75 \pm 0.87$ & -4.65 & 0.0001 \\
\hline Importance & $3.14 \pm 0.93$ & $3.12 \pm 0.89$ & 0.37 & 0.721 \\
\hline Incentive by parents & $2.72 \pm 0.92$ & $2.71 \pm 0.92$ & 0.40 & 0.685 \\
\hline Incentive by friends & $2.79 \pm 0.80$ & $2.82 \pm 0.78$ & -2.90 & 0.005 \\
\hline Incentive, general & & & & \\
\hline
\end{tabular}

the importance of physical activity and the incentive to be physically active improved statistically significantly $(\mathrm{p}<0.05)$ among the adolescents of the impact group facing problems linked to physical activity.

In the comparison group, neither athletic identity nor its constituents exhibited statistically significant changes $(p>0.05)$.
In terms of the aspect of gender, values of athletic identity in both males and females during the period of educational counseling improved statistically significantly ( $p<0.05$ ). However, when evaluating specific constituents of athletic identity, certain differences were observed. Both males and females exhibited significant $(p<0.05)$ 
improvement of physical activity evaluations, while only females showed statistically significant increase in social (general) incentive.

The impact of educational counseling on athletic identity was insignificant $(p>0.05)$ in those adolescents who were facing problems in communication with teachers of physical education.

Educational counseling was more efficient in adolescents who had been involved in physical education classes insufficiently. They significantly $(p<0.05)$ increased the evaluations not only of the athletic identity but also those of the importance of physical activity and the social (general) incentive.

\section{DISCUSSION}

The obtained results of the research reveal that the social incentive to be physically active receives lower evaluation among adolescents than other constituents of athletic identity. Regarding the need of an adolescent to be physically active, the social environment plays one of the key roles (Bélanger et al., 2011).

The method of educational counseling is directed towards behavioral changes in the adolescent; as other researchers suggest (Peterson, 2005; Anshel, Seipel, 2009), such counseling can alter even previously acquired incorrect life habits.

During the period of counseling, motivation, i. e. the inclination of students to do something in order to decrease the urgency of the problem, gradually increased from the first session onwards, which marks the positive disposition of adolescents to deal with the arising problems in the physical activity and other topical fields. Thus, it is likely that students consider educational counseling to be acceptable; this incites students to look for solutions and to substitute non-adaptive behavior by constructive behavior. It also promotes their willingness to address a counselor next time with a new problem arising, provided it cannot be solved by the student him/herself.

The obtained results of the research suggest that with the help of educational counseling, physical activity and other urgent problems may be efficiently solved as the subjective evaluation of the pointed out problems systematically decreased from the first counseling session onwards. After three sessions, moderate or prominent changes (i. e. the subjective solution of the problem) were indicated by 65.6 per cent of the counseled individuals. Similar results were obtained by other authors (Shefler, 2000; Kvarme et al., 2010; Niemi, Tiuraniemi, 2010).

Part of the students seeking counseling regarding problems connected with physical activity also faced difficulties in communication with teachers of physical education, this was not an exceptional case typical of only this research. The qualitative research by V. Fominiene (2007) showed that during classes of physical education, communication and cooperation problems frequently occurred. It is likely that the arising obstacles of pedagogical communication in the educational process should be dealt with by applying additional educational measures, i. e. educational counseling thus ensuring proper promotion of physical activity among students.

The least significant changes in athletic identity after educational counseling were observed among those students who were involved in counseling regarding problems in interaction with teachers of physical education, while the most prominent changes took place regarding insufficient involvement in classes of physical education. Hence the most vulnerable group of students whose athletic identity prior to educational counseling was the least prominent indicated the greatest changes in athletic identity after educational counseling.

During the research, part of the students participated only in two counseling sessions claiming that they achieved the previously stated objectives. From our point of view, this indicates that the solution of certain urgent problems among adolescents may be efficiently provided by the method of educational counseling. Other researchers express the same opinion (Shefler, 2000; Pourebrahim et al., 2011).

The results of this research corroborate data provided by other authors indicating that the efficiency of educational counseling is unrelated with the gender of the counseled individual (Goštautas et al., 2005). Educational counseling provides an adolescent with an alternative of behavior as orientation towards solutions is undertaken in the current troublesome (from the adolescent's point of view) situation instead of accusation of the adolescent regarding improper behavior or his/ her previous failures. Hence, the counseled individual rather than the counselor creates the efficiency of the method (Williamson, 2008). 
Adolescents are given coherent questions; thus the counselor not only gathers information on the problems faced by the adolescent, but also creates a favorable environment of cooperation. This helps with the development of an empathic attitude of the counselor towards the global outlook of the adolescent and the creation of the positive relationship between the adolescent and the counselor providing preconditions of outlining specific and clear objectives in the process of counseling (Frels et al., 2009).

After educational counseling, manifestation of athletic identity and physical activity in adolescents was positively altered. In the course of this educational experiment, an impact on the development of the positive physical "self" was planned. As the feeling of athletic identity is under permanent development (Tasiemski et al., 2004), its promotion is feasible anytime. Better results are likely to be achieved if athletic identity is promoted since childhood, for example, since primary school. Yet it is not clear whether the method of educational counseling could be suitable for children and adolescents of various ages.

The results of the research revealed that educational counseling was a suitable method for dealing with problems of physical activity in students and pedagogical communication obstacles during the physical education classes. This is also highlighted in other research claiming that educational counseling may be efficient in dealing with physical activity problems (Williams, Strean, 2005; Lin et al., 2010).

Other researchers stress the efficiency of this method in the cases of its application by teachers (Murphy, 1994), psychologists (Williams, Strean,
2005), social pedagogues or society health developers (Franklin et al., 2008).

When considering the peculiarities of the age of adolescence and the inconsistency of problems or the changes in personality, it is possible to claim that educational counseling should be applied not only as a one-time tool of the stimulation of the education process but rather as a regular supportive measure.

\section{CONCLUSIONS AND PERSPECTIVES}

1. Educational counseling positively affects changes in the athletic identity of adolescents.

2. During the period of educational counseling, the evaluations of athletic identity and its components, the importance of physical activity and incentives to undertake physical activity increased statistically significantly $(p<0.05)$ among adolescents facing problems connected with physical activity.

3. The evaluations of athletic identity in males and females during the period of educational counseling improved statistically significantly $(\mathrm{p}<0.05)$.

4. The impact of educational counseling on the athletic identity was insignificant $(p>0.05)$ in those adolescents who had problems in communication with teachers of physical education.

The future prospects of the research are related with the investigation of the suitability of the method of educational counseling for children and adolescents in various age groups.

\section{REFERENCES}

Anderson, C. B. (2004). Athletic identity and its relation to exercise behavior: Scale development and validation. Journal of Sport \& Exercise Psychology, 26 (1), 39-56.

Anderson, C. B., Masse, L. C., Hergenroeder, A. C. (2007). Factorial and construct validity of the athletic identity questionnaire for adolescents. Medicine and Science in sports and Exercise, 39 (1), 59-69.

Anshel, M., Seipel, S. (2009). Self-monitoring and selected measures of aerobic and strength fitness and short-term exercise attendance. Journal of Sport Behavior, 32 (2), 125-151.

Bélanger, M., Casey, M., Cormier, M. et al. (2011). Maintenance and decline of physical activity during adolescence: Insights from a qualitative study. Journal of Behavioral Nutrition and Physical Activity, 8 (1), 117-125.

Fominienè, V. (2007). Kūno kultūros mokytoju nuostata dèl pedagoginès komunikacijos kaip mokiniu požiūrio i kūno kultūros ugdymasi determinantè: daktaro disertacija. Kaunas: Lietuvos kūno kultūros akademija.

Franklin, C., Moore, K., Hopson, L. (2008). Effectiveness of solution-focused brief therapy in a school setting. Children Schools, 30 (1), 15-26.

Frels, R., Leggett, E. S., Larocca, P. (2009). Creativity and solution-focused counseling for a child with chronic illness. Journal of Creativity in Mental Health, 4 (4), 308-319. 
Goštautas, A., Čepukienè, V., Pakrosnis, R., Fleming, J. S. (2005). The outcome of solution focused brief therapy for adolescent foster care and health care institutions. Baltic Journal of Psychology, 6 (2), 5-14.

Kvarme, L. G., Helseth, S., Sørum, R. et al. (2010). The effect of a solution-focused approach to improve selfefficacy in socially withdrawn school children: A nonrandomized controlled trial. International Journal of Nursing Studies, 47 (11), 1389-1396.

Laus, M. F., Costa, T. M. B., Almeida, S. S. (2011). Body image dissatisfaction and its relationship with physical activity and body mass index in Brazilian adolescents. Journal Brasileiro de Psiquiatria, 60 (4), 315-320.

Lawler, M., Nixon, E. (2011). Body dissatisfaction among adolescent boys and girls: The effects of body mass, peer appearance culture and internalization of appearance ideals. Journal of Youth and Adolescence, 40 (1), 59-71.

Lee, P. H., Macfarlane, D. J., Lam, T. H., Stewart, S. M. (2011). Validity of the international physical activity questionnaire short form (IPAQ-SF): A systematic review. International Journal of Behavioral Nutrition and Physical Activity, 8-115.

Lekečinskaitè, D. (2009). Tarptautinio fizinio aktyvumo klausimyno ilgosios ir trumposios versiju lietuviškos versijos parengimas ir aprobavimas: magistro baigiamasis darbas. Kaunas: LKKA.

Lin, J. S., O’Connor, E., Whitlock, E. P., Beil, T. L. (2010). Behavioral counseling to promote physical activity and a healthful diet to prevent cardiovascular disease in adults. Annals of Internal Medicine, 153 (11), 736-750.

Murphy, J. J. (1994). Working with what works: A solution-focused approach to school behavior problems. The School Counselors, 42, 59-65.

Niemi, P. M., Tiuraniemi, J. (2010). Cognitive therapy trainees' self-reflections on their professional learning. Behavioural \& Cognitive Psychotherapy, 38 (3), 255-274.
Peterson, Y. (2005). Family therapy treatment: Working with obese children and their families with small steps and realistic goals. Acta Paediatrica, 94 (488), 42-44.

Pourebrahim, T., Khoshkonesh, A., Salehi, F. (2011). Effects of solution focused counseling on increasing educational performance and Self-efficacy in highschool students girls. Career and Organizational Counseling, 3 (6), 62-80.

Shefler, G. (2000). Time-limited psychotherapy with adolescents. Journal of Psychoterapy Practice \& Research, 9 (2), 88-99.

Shek, D. T. L., Wong, K. K. (2011). Do adolescent developmental issues disappear overnight? Reflections about holistic development in university students. The Scientific World Journal, 11, 353-361.

Simon, J. K., Berg, I. K. (1999). Solution-focused brief therapy with long-term problems. Directions in Rehabilitation Counseling, 10, 117-128.

Tasiemski, T., Kennedy, P., Gardner, B., Blaikley, R. A. (2004). Athletic identity and sports participation in people with a spinal cord injury: A psychometric evaluation of the Athletic Identity Measurement Scale. Adapted Physical Activity Quarterly, 21, 364-378.

Videon, T. M. (2002). Who plays and who benefits: Gender, interscholastic athletics, and academic outcomes. Sociological Perspectives, 45 (4), 415-444.

Weiss, M. R., Willaims, L. (2004). The why of youth sport involvement: A developmental perspective on motivation processes. In M. R. Weiss (Ed.), Developmental Sport and Exercise Psychology: A Lifespan Perspective (pp. 223-268). Morgantown, Wv: Fitness Information Technology.

Williams, D. J., Strean, W. B. (2005). Little pain, much gains Solution-focused counseling on physical activity. Canadian Family Physician, 51 (5), 677-678.

Williamson, A. (2008). Brief Psychological Interventions in Practice. The Atrium, Southern Gate, Chichester, West Sussex, England: John Wiley \& Sons Ltd.

\title{
EDUKACINIO KONSULTAVIMO POVEIKIS PAAUGLIU SPORTINIO TAPATUMO KAITAI
}

\author{
Vinga Rakauskienė, Audronė Dumčienè \\ Lietuvos kūno kultūros akademija, Kaunas, Lietuva
}

\section{SANTRAUKA}

Tyrimo pagrindimas ir hipotezė. Straipsnyje nagrinèjama vyresniujų klasių moksleivių sportinio tapatumo raiška kaip svarbi prielaida ugdant jaunuolių kūno kultūrą ir sveikatai palankų fizinį aktyvumą visam gyvenimui (Anderson, 2004; Bélanger, et al., 2011). Hipotezè: dèl edukacinio konsultavimo paauglių sportinio tapatumo įverčiai gerèja.

Tikslas - išsiaiškinti edukacinio konsultavimo poveiki paauglių sportinio tapatumo kaitai. 
Metodai. Paaugliu sportiniam tapatumui paveikti naudota edukacinio konsultavimo metodika. Paauglio problemai atskleisti buvo naudojami keturių rūšių klausimai: Išimčių, Stebuklo, Susidorojimo, Skalės ir Veiksmų apibūdinimo. Fiziniam aktyvumui vertinti naudota adaptuota trumpoji IPAQ septynių klausimų forma, sportinio tapatumo vertinimui - adaptuotas Athletic Identity Questionnaire for Adolescents (Anderson et al., 2007) klausimynas iš 40 teiginių, kuriuos konsultuojamieji vertino Likert skalèje nuo 1 iki 5.

Buvo tiriami 553 moksleiviai (amžiaus vidurkis - 16,75 $\pm 1,11$ m.), tarp kurių 294 merginos ir 259 vaikinai. Moksleiviai atsitiktinès atrankos būdu buvo paskirstyti i edukacinio konsultavimo poveikio (253 paaugliai) ir lyginamają (300 paaugliu) grupes. Poveikio grupès tiriamieji konsultuoti dẻl fizinio aktyvumo ir kitu problemų nuo 1 iki 6 kartų, o lyginamosios grupés paaugliai nurodè turi fizinio aktyvumo ir kitų problemų, bet nebuvo konsultuoti.

Rezultatai. Sportinio tapatumo ir jo komponenčiųiverčiai prieš edukacinį konsultavimą poveikio ir lyginamosios grupės paauglių reikšmingai nesiskyrė ( $\mathrm{p}>0,05)$.

Edukacinio konsultavimo laikotarpiu statistiškai reikšmingai $(\mathrm{p}<0,05)$ pagerejo poveikio grupès fizinio aktyvumo problemų turèjusių paauglių sportinio tapatumo, jo komponenčių fizinio aktyvumo svarbos ir fizinio aktyvumo paskatos įverčiai.

Edukacinis konsultavimas buvo veiksmingesnis tarp paauglių, nepakankamai įsitraukusių i kūno kultūros pamokas. Reikšmingai $(\mathrm{p}<0,05)$ pagerejo ne tik jų sportinio tapatumo, bet ir fizinio aktyvumo svarbos bei socialinės paskatos (bendros paskatos) ìverčiai.

Aptarimas ir išvados. Edukacinis konsultavimas teigiamai veikia paauglių sportinio tapatumo kaitą. Edukacinio konsultavimo laikotarpiu statistiškai reikšmingai $(\mathrm{p}<0,05)$ pagerėjo fizinio aktyvumo problemų turèjusių paauglių sportinio tapatumo bei jo komponenčių fizinio aktyvumo svarbos ir paskatos ivverčiai. Merginų ir vaikinų sportinio tapatumo iverčiai edukacinio konsultavimo laikotarpiu pagerejo statistiškai reikšmingai ( $p<0,05)$. Edukacinis konsultavimas reikšmingai nepaveikè sportinio tapatumo $(\mathrm{p}>0,05)$ tų paauglių, kurie turèjo bendravimo su kūno kultūros mokytojais problemų.

Raktažodžiai: edukacinis konsultavimas, moksleiviai, sportinis tapatumas, fizinis aktyvumas.

Gauta 2012 m. spalio 25 d.

Received on October 25, 2012

Priimta 2012 m. gruodžio 5 d.

Accepted on December 5, 2012
Corresponding author Vinga Rakauskienè Lithuanian Academy of Physical Education Sporto str. 6, LT-4422 Kaunas

Lithuania

Tel +370 37209050

E-mail vinga_r@yahoo.com 